Www.jmscr.igmpublication.org

Impact Factor (SJIF): 6.379

Index Copernicus Value: 79.54

ISSN (e)-2347-176x ISSN (p) 2455-0450

crossrefDOI: https://dx.doi.org/10.18535/jmscr/v6i8.23

Journal Of Medical Science And Clinical Research

IGM Publication

An official Publication of IGM Publication

\title{
Short term low dose oral steroid- an effective treatment of Carpal Tunnel Syndrome
}

\author{
Authors \\ Dr Md Mahbubul Alam¹, Dr Shamim Rashid ${ }^{2}$, Dr Abdul Halim Sarder ${ }^{3}$ \\ ${ }^{1}$ Assistant Professor, Department of Neurology, M Abdur Rahim Medical College, Dinajpur, Bangladesh \\ ${ }^{2}$ Assistant Professor, Department of Neurology, Sheikh Hasina Medical College, Tangail, Bangladesh \\ ${ }^{3}$ Assistant Professor, Department of Neurology, Khulna Medical College, Khulna, Bangladesh
}

\begin{abstract}
Introduction: Carpal tunnel syndrome (CTS) may be defined as the compression of the median nerve at the wrist (carpal tunnel) in absence of an obvious injury, trauma or surgery. This is the commonest entrapment neuropathy.

Methods: This prospective case-control study was undertaken in the Department of Neurology (outdoor and electrophysiology centre), Bangabandhu Sheikh Mujib Medical University (BSMMU), Dhaka, during period from January to December, 2005. The objective of this study was to observe the efficacy of shortterm low-dose steroid in mild to moderate idiopathic carpal tunnel syndrome. Total number of 60 respondents consisting of 30 subjects as control and 30 subjects as case, who were clinically and electrodiagnostically diagnosed as a CTS. The control and case respondents were age, sex and socioeconomic status matched. The clinical details and investigations of the respondents were reviewed. Data were recorded in predesigned proforma.

Out of 30 control and 30 cases, 8 (26.7\%) were male and $22(73.3 \%)$ female in each group. Majority of the cases presented at fourth to fifth decade of life.

Patients having history of diabetes mellitus, hypothyroidism, rheumatoid arthritis and cervical spondylitis were excluded from the study.

Mean (+ SD) age of the study subjects was $39.47+7.90$ years. Females were affected more than male. All the subjects underwent GSS (global symptoms score) by questionnaire and median and ulnar nerve conduction scoring in the conventional way following guidelines of the American Academy of Electrodiagnostic Medicine.

Results: After treatment with short-term low-dose oral prednisolone, GSS improved in 56.3\% and electrophysiological parameters found to be improved significantly. These results were compared with those of the western and Indian subcontinent studies and found to be similar and consistent.

Keywords: Carpal tunnel syndrome (CTS), Short term low dose oral steroid, Diabetes mellitus, GSS (global symptoms score).
\end{abstract}

\section{Introduction}

The carpal tunnel is a passageway of the wrist on the palmer side which is connected to the forearm to the hand. The carpal tunnel syndrome (CTS) is a medical condition that caused by compression of the median nerve as it travels through the wrist at 
the carpal tunnel. The Signs and symptoms are numbness, pain and tingling sensation. The most common early symptom of CTS is the intermittent tingling paraethesia of the palmar aspect of the first three and half digits and lateral two-thirds of the hand of the affected side. At present, Carpal tunnel syndrome is the most common entrapment neuropathy. ${ }^{[1]}$ The other less common forms of entrapment of neuropathies are cubital tunnel syndrome (cubital tunnel syndrome is a condition that involves pressure or stretching of the ulnar nerve at the elbow. It is also known as the "funny bone" nerve), tarsal tunnel syndrome (tarsal tunnel syndrome is a compression neuropathy and painful foot condition), meralgia paraesthetica (Meralgia paresthetica is pain or numbness in the outer thigh. It does not caused by injury to the thigh, it causes by injury to a nerve that extends from the spinal column to the thigh) and so on.

Women are three times more susceptible to carpal tunnel syndrome than men. The prevalence of CTS in general western European population has been estimated to be at $3 \%$ to $5.8 \%$ for women and $0.6 \%$ to $2.1 \%$ for men. ${ }^{[2]}$

This disease affect the dominant hand first the tingling of hand becomes more continuous as the disease progress, frequently associated with pain of the affected hand, and ultimately wasting of muscles on the palm and weakness of the grip. For most patients, the cause of their carpal tunnel syndrome is unknown. Any condition that exerts pressure on the median nerve at the wrist can cause carpal tunnel syndrome. Common conditions that can lead to carpal tunnel syndrome include obesity, pregnancy, hypothyroidism, arthritis, diabetes, and trauma though in many cases there are none. Tendon inflammation resulting from repetitive work, such as uninterrupted typing, can also cause carpal tunnel symptoms. Carpal tunnel syndrome from repetitive maneuvers has been referred to as one of the repetitive stress injuries, although this relationship remains controversial in the evidence based literature. Some rare diseases can cause deposition of abnormal substances in and around the carpal tunnel, leading to nerve irritation. These diseases include amyloidosis, sarcoidosis, multiple myeloma, and leukemia. ${ }^{3}$

Persons with diabetes or other metabolic disorders are also at high risk of CTS. Usually CTS affects only the adults. 4

Treatments are available for CTS, such as medications or surgeries. This research is to see the low dose of steroids is effective on carpal tunnel syndrome or not.

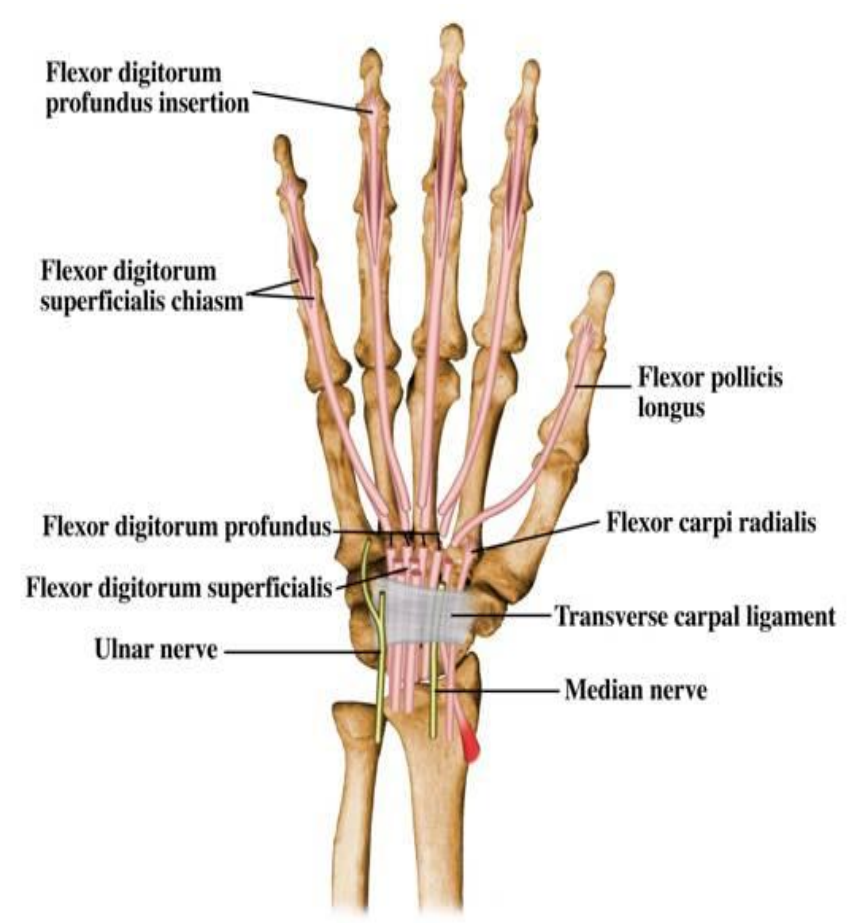

Figure 1 Relation of the bones, muscles and median nerve of the hand to the flexor retinaculum (transverse carpal ligament) 


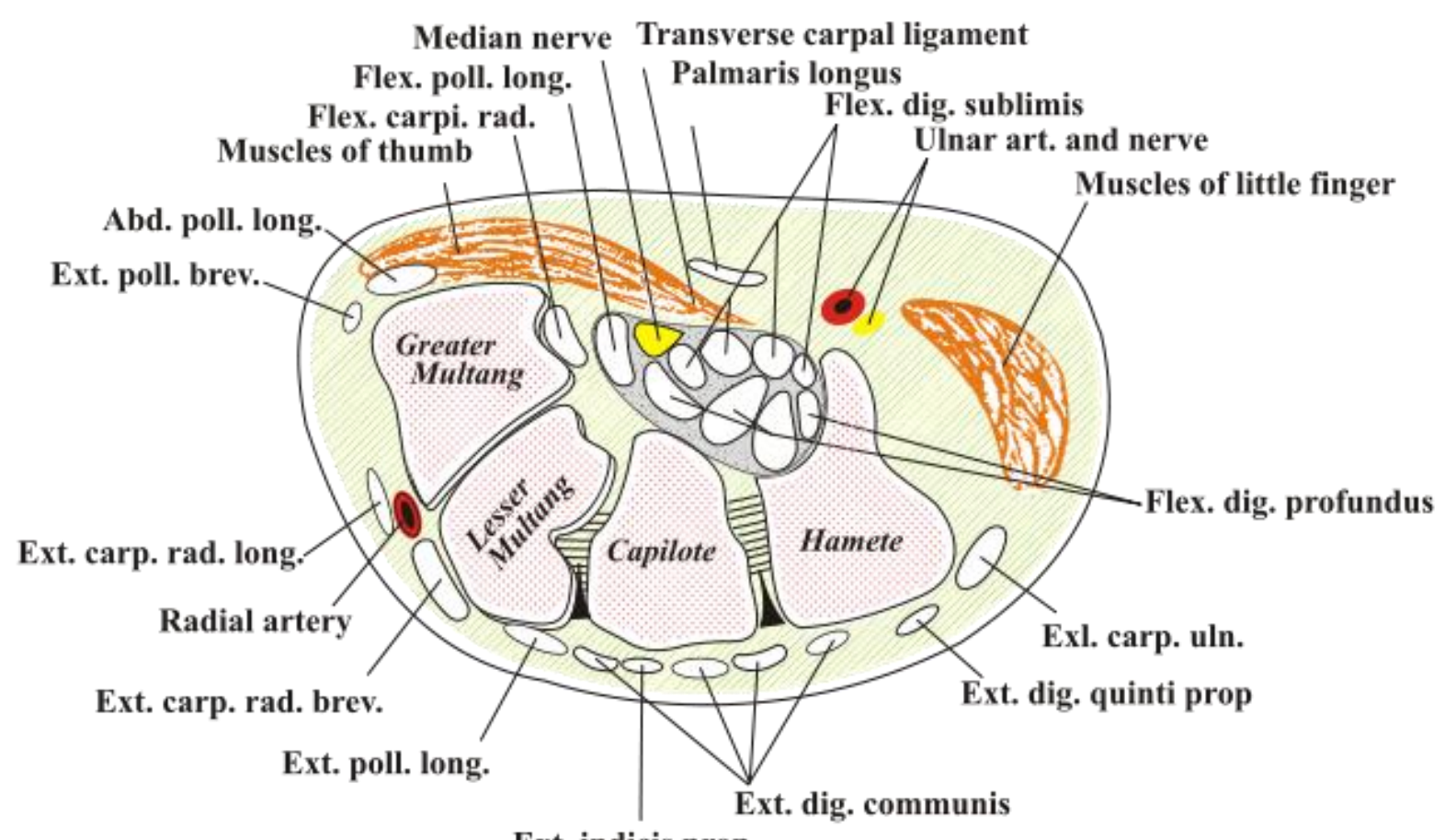

Ext. indicis prop.

Figure 2 Transverse section through the left wrist, showing the contents of the carpal tunnel (red boxed area) and their relation to each other and to the other structures at this level.

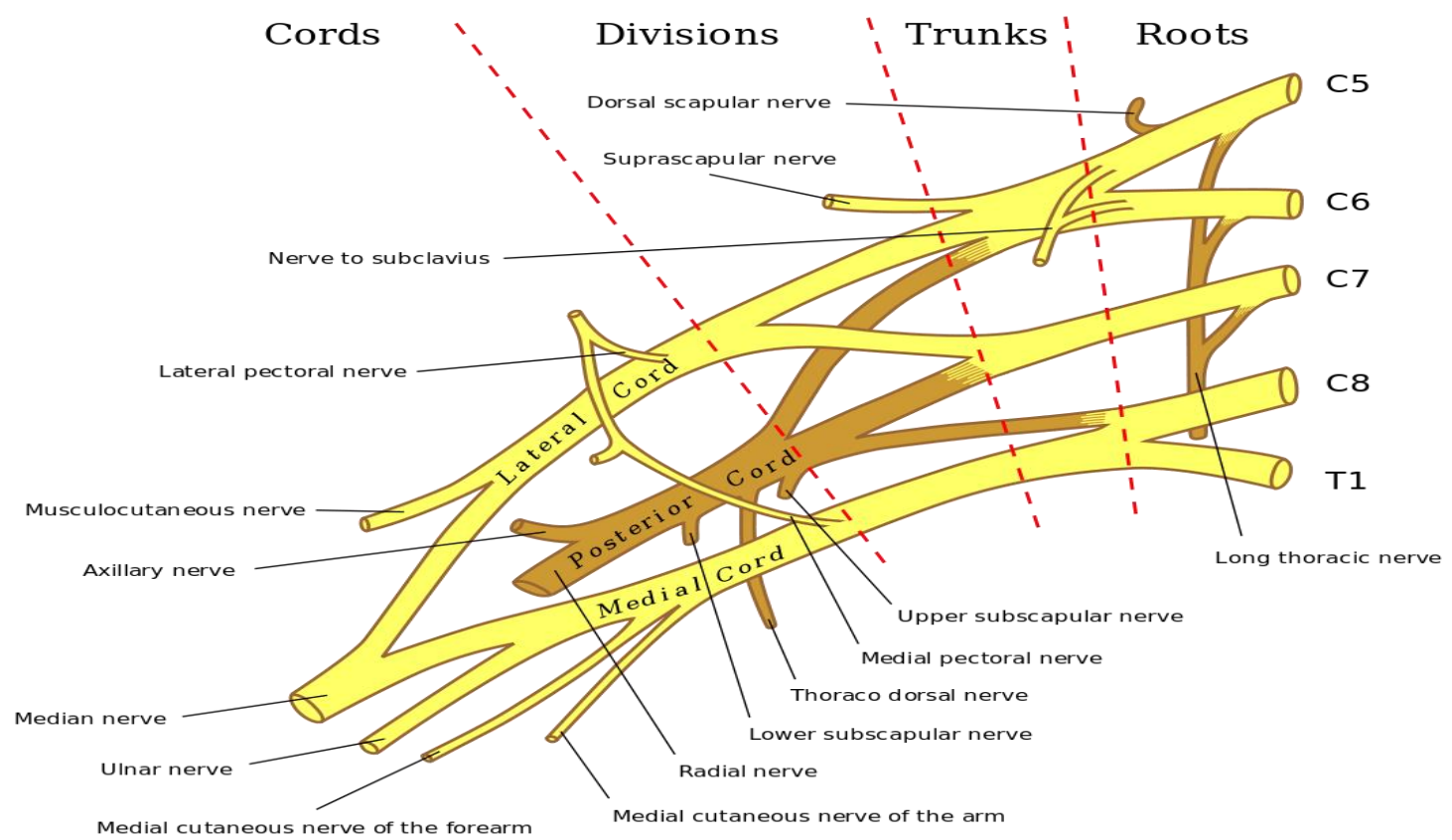

Fig. 3 Brachial plexus showing the formation of median and ulnar nerves 


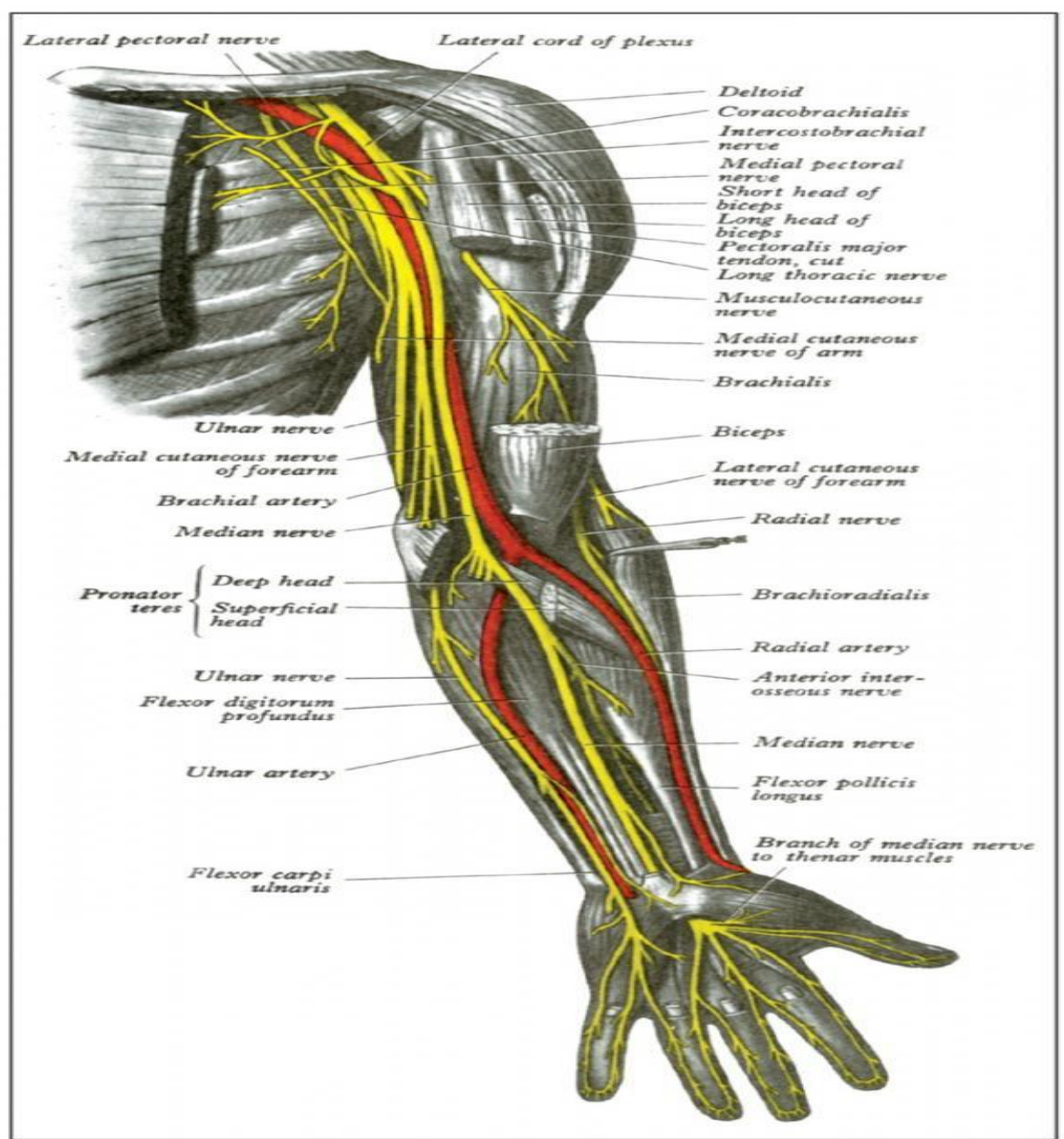

Fig. 4 The nerves of the upper limb dissected from the anterior aspect, showing the course of median and ulnar nerves, their branches and their relation with other structures (After Chummy and Sinnatam by, 1999).

\section{Objective}

\section{The general aim of the study is}

To find out the response of low-dose short-term oral steroid in mild to moderate carpal tunnel syndrome.

\section{The specific objectives are}

$>$ To correlate the clinical features of patients with carpal tunnel syndrome (CTS) with electrophysiological parameters.

To find out the socio demographic characteristics of the patients with CTS.

To assess the severity of CTS on clinical and electrophysiological basis.

To find out the associated conditions/diseases along with CTS.

\section{Methodology}

Table-1: Study type, place of study and duration

\begin{tabular}{|l|l|l|}
\hline Study type: & Place of study & $\begin{array}{l}\text { Duration of } \\
\text { study }\end{array}$ \\
\hline $\begin{array}{l}\text { Prospective case- } \\
\text { control study }\end{array}$ & $\begin{array}{l}\text { Department of } \\
\text { Neurology, } \\
\text { Bangabandhu } \\
\text { Sheikh Mujib } \\
\text { Medical University } \\
\text { (BSMMU) }\end{array}$ & $\begin{array}{l}\text { The study period } \\
\text { was one year, } \\
\text { from January to } \\
\text { December, 2005 }\end{array}$ \\
\hline
\end{tabular}

\section{Study population}

Control: Subjects who were diagnosed clinically and electro physiologically as CTS treated with physiotherapy.

Case: Patients attending the outdoor of Department of Neurology, BSMMU, designated as clinically suspected CTS and established by electrophysiological parameters and treated for 4 weeks with oral steroids. 


\section{Sample size}

There were two groups of samples. One group of 30 patients was designated as control and another group of 30 patients designated as cases. Both the groups were matched in respect to age and sex and CTS symptoms for more than 3 months.

\section{Sample size determination}

Sample size of this study was determined purposively by the researcher considering all resource constrains like limited time, financial support and availability of study subjects.

\section{Sampling technique}

The study was conducted by using convenient type of non-probability sampling technique. As the sophisticated diagnostic facility of NCS is limited in context of Bangladesh, the researcher used the mentioned sampling technique.

\begin{tabular}{|c|c|}
\hline $\begin{array}{l}\text { Inclusion } \\
\text { (Clinical) }\end{array}$ & $\begin{array}{ll}\text { Inclusion } & \text { criteria } \\
\text { (Electrophysiological) }\end{array}$ \\
\hline $\begin{array}{l}\text { a) Symptoms of CTS } \\
\text { for more than } 3 \text { months, } \\
\text { i.e. tingling numbness or } \\
\text { pain referred to the } \\
\text { palmar aspect of the first } \\
\text { three and half digits and } \\
\text { radial half of the palm. } \\
\text { b) Above symptoms } \\
\text { exacerbated by work } \\
\text { with symptomatic hand } \\
\text { c) Nocturnal } \\
\text { exacerbation of the } \\
\text { symptoms sign } \\
\text { d) Positive Tinel's sian manoeuvre } \\
\text { and phalen me of the } \\
\text { e) Absence of any of } \\
\text { exclusion criteria }\end{array}$ & $\begin{array}{l}\text { a) Median sensory distal } \\
\text { latency more than } 3.1 \mathrm{~ms} \\
\text { b) Median motor distal } \\
\text { latency more than } 4.4 \mathrm{~ms} \\
\text { c) Difference between distal } \\
\text { motor latency of median and } \\
\text { ulnar nerve more than } 1.1 \mathrm{~ms} \\
\text { d) Difference between distal } \\
\text { sensory latency of median and } \\
\text { ulnar nerve more than } 0.2 \text { ms } \\
\text { e) EMG of abductor polices } \\
\text { brevis: Mild describes decreased } \\
\text { conduction velocity over the } \\
\text { palm wrist segments and } \\
\text { delayed SDL with normal } \\
\text { median SNAP amplitude and } \\
\text { CMAP amplitude of abductor } \\
\text { polices brevis. Moderate } \\
\text { describes patient with } \\
\text { abnormality delayed MDL and } \\
\text { SDL with either decreased } \\
\text { median SNAP amplitude or } \\
\text { decreased CMAP amplitude of } \\
\text { the abductor polices brevis. }\end{array}$ \\
\hline
\end{tabular}

\section{Exclusion criteria}

a) Symptoms less than 3 months

b) CTS-like condition seems as clinical cervical radiculopathy, proximal median neuropathy or significant polyneuropathy c) Exclusion of hypothyroidism, diabetes mellitus, pregnancy, vibrating users

d) Cognitive impairment interfering with subjects ability to follow instructions and describe symptoms

e) Recent peptic ulcer or history of steroid intolerance

f) Presence of either fibrillation potential or reinnervation on needle electromyography (EMG) in abductor brevis muscle (to ensure the inclusion of mildly or moderately affected individual

\section{Data collection tools}

Questionnaire Both groups of subjects were collected by structured questionnaire of five major symptoms of CTS:

a) Numbness

b) Pain

c) Weakness/clumsiness

d) Tingling

e) Nocturnal awakening Scale: 0 (nil) to 10 (severe)

According GSS, CTS is classified into mild, moderate and severe groups:

Mild : GSS up to 15

Moderate : $16-35$

Severe : $36-50$

Resulting global symptoms score (GSS) was evaluated. The efficacy of treatment assessments were made at baseline and at one month. Electrodiagnosis was repeated at the end of the study to validate improvement.

\section{Procedure of NCS}

Motor and sensory nerve conduction study (NCS) of the median nerves was done using the conventional techniques. This was done by a machine which is a particular hardware fitted with a computer. The hardware is loaded with particular software. The special hardware has a separate keyboard, patient input box, stimulating and recording electrodes. The machine requires separate isolated power supply and grounding to avoid electrical artifacts. The studies were performed using standard recording stainless disc 
electrode, stainless steal ground, ring electrode and bipolar surface stimulator. The standard filer settings for motor $(2-10,000 \mathrm{~Hz})$ and sensory $(10-$ $5,000 \mathrm{~Hz}$ ) studies were used. Stimulus strength $10-15 \%$ above the maximal stimuli skin temperature was maintained between 32 and $34^{\circ} \mathrm{C}$ as far as possible.

The compound muscle action potential was recorded with a surface electrode placed on the belly of the abductor pollicis brevis (APB) muscle. The reference electrode was placed $3 \mathrm{~cm}$ distal to the recording electrode. Motor nerve conduction velocity was calculated for each patient by stimulating the nerve at the wrist (placed $7 \mathrm{~cm}$ proximal to the recording electrode) and elbow using supramaximal stimuli. The motor distal latency was measured from the stimulus artifact to the onset of action potential. The sensory NCS was done by stimulating the digital branches of the nerve again using supramaximal stimuli and recording from the wrist.

Motor and sensory NCS of the ulnar nerve were done in a similar way. Needle electromyography in abductor pollicis brevis muscle was done for presence of either fibrillation potential or reinnervation.

\section{Diagnostic criteria for CTS}
a) Median sensory distal latency $>3.1 \mathrm{~ms}$
b) Median motor distal latency $>4.4 \mathrm{~ms}$
c) Difference between distal motor latency of median and ulnar nerve $>1.1 \mathrm{~ms}$

d) Difference between distal sensory latency of median and ulnar nerve $>0.2 \mathrm{~ms}$

The study was divided into two groups as follows:

\section{a) Control group}

In this group, NCS was done on 30 patients referred to the centre with positive symptoms and/or signs suggestive of unilateral or bilateral CTS. Selected demographic data including age and sex, and the clinical features were systematically recorded. After 4 weeks of physiotherapy, NCS and clinical assessments were done.

\section{b) Case group}

In this group, NCS was done on 30 patients referred to the centre with positive symptoms and signs suggestive of unilateral or bilateral CTS. Selected demographic data including age and sex, and clinical features were systematically recorded. After 4 weeks of oral prednisolone, NCS and clinical assessments were done.

\section{Data processing}

All relevant information from history, clinical examinations and investigations were collected in a predesigned data collection sheet (Appendix-I).

\section{Data analysis}

Collected data were compiled and appropriate analyses done by using computer based software, Statistical Package for Social Science (SPSS). P value $<0.05$ was taken as minimum level of significance. 


\section{Results}

A total number of 30 control and 30 cases of age and sex matched respondents were examined.

Table-I. Socio demographic characteristics of the study subjects

\begin{tabular}{|c|c|c|c|c|c|}
\hline Parameters & \multicolumn{2}{|c|}{ Control $(n=30)$} & \multicolumn{2}{|c|}{ Case $(n=30)$} & $P$ value \\
\hline Mean+SD & & & \multicolumn{2}{|c|}{ Mean \pm SD } & \\
\hline Age (years) & 38. & $73+7.25$ & 39. & $47+7.90$ & $>0.50^{\mathrm{ns}}$ \\
\hline \multirow[t]{2}{*}{ Weight (kg) } & 58. & $83 \pm 5.59$ & 56. & $83 \pm 6.97$ & $>0.10^{\mathrm{ns}}$ \\
\hline & No & - $\quad(\%)$ & No & $-\quad(\%)$ & \\
\hline \multirow{2}{*}{ Sex Male Female } & 8 & $(26.7)(73.3)$ & 8 & $>0.50^{\mathrm{ns}}(26.7)$ & \\
\hline & 22 & & 22 & $\begin{array}{l}(73.3) \\
>0.50^{\mathrm{ns}}\end{array}$ & \\
\hline Farmer & 3 & $(10.0)$ & 3 & $(10.0)$ & \\
\hline Daylabourer Clinical job & 1 & $(3.3)$ & 0 & & \\
\hline Official job & 4 & $(13.3)(10.0)$ & 3 & $(10.0)$ & \\
\hline Student & 3 & & 4 & (13.3) & \\
\hline Housewife & 0 & $(63.3)$ & 1 & $(3.3)$ & \\
\hline & 19 & & 19 & $(63.3)$ & \\
\hline
\end{tabular}

Chi-square test/Unpaired Student's 't' test ns = not significant

In the table-I, mean $( \pm \mathrm{SD})$ age of the control was $38.73+7.25$ years and in case group was $39.47+$ 7.90 years. The study of ex distribution showed that male and female were equally distributed between control and case groups (26.7\% male and 73.3\% female). Analysis revealed that no statistically significant difference was found between the sex distributions of the patients of the two groups $(\mathrm{P}>0.05)$. Mean $(+\mathrm{SD})$ weight of the control group was $58.83+5.59 \mathrm{~kg}$ and case group $56.83 \pm 6.67 \mathrm{~kg}$. Besides, table also showed that housewives were equally affected in both control and case groups (63.3\% control and $63.3 \%$ case). Mean difference was not statistically significant

Table-II Findings on examination of hands

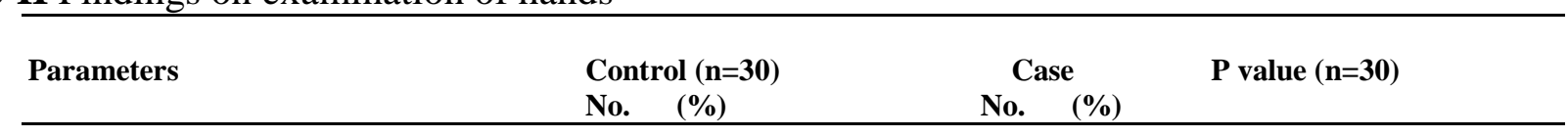

\section{Sensory function along median nerve}

\begin{tabular}{|c|c|c|c|c|c|}
\hline & \multirow[t]{2}{*}{$>0.50^{\mathrm{ns}}$} \\
\hline Right & & & & & \\
\hline Normal & 4 & $(13.3)$ & 5 & $(16.7)$ & \\
\hline Hyperesthesia & 26 & $(86.7)$ & 25 & $(83.3)$ & \\
\hline Left & & & & & $>0.10^{\mathrm{ns}}$ \\
\hline Normal & 4 & (13.3) & 6 & $(20.0)$ & \\
\hline Hyperesthesia & 26 & (86.7) & 24 & $(80.0)$ & \\
\hline Tinel's sign & & & & & $>0.10^{\mathrm{ns}}$ \\
\hline Positive & 27 & $(90.0)$ & 23 & (76.7) & \\
\hline Negative & 3 & $(10.0)$ & 7 & $(23.3)$ & \\
\hline Phalen manoeuvre & & & & & $>0.50^{\mathrm{ns}}$ \\
\hline Positive & 17 & $(56.7)$ & 17 & $(56.7)$ & \\
\hline Negative & 13 & $(43.3)$ & 13 & $(43.3)$ & \\
\hline
\end{tabular}


In table II, hyperesthesia along the median nerve in control group were $86.7 \%$ (right) and $86.7 \%$ (left), and in case group were $83.3 \%$ (right) and $80 \%$ (left). Tinel's sign was positive in $90 \%$ control and in $76.7 \%$ case group. Phanel manoeuvre were positive in $56.7 \%$ control and $56.7 \%$ case group. Analysis revealed that no statistically significant distribution was found between the patients of the two groups $(\mathrm{P}>0.50)$.

Table-Ill Measurement of treatment response on pain score in control $(n=30)$ and case $(n=30)$ groups

\begin{tabular}{|c|c|c|c|c|}
\hline \multirow[b]{2}{*}{ Pain Score } & \multicolumn{2}{|c|}{ Measurement of response } & \multirow{2}{*}{$\begin{array}{l}\text { Percent }(\%) \text { change } \\
\text { from before } \\
\text { treatment to after } \\
\text { treatment }\end{array}$} & \multirow[b]{2}{*}{$P$ value } \\
\hline & $\begin{array}{c}\text { Before } \\
\text { treatment }(\text { Mean } \pm \text { SD) }\end{array}$ & $\begin{array}{l}\text { After treatment } \\
(\text { Mean } \pm \text { SD })\end{array}$ & & \\
\hline $\begin{array}{c}\text { Right } \\
\text { Control } \\
\text { Case }\end{array}$ & $\begin{array}{l}3.30 \pm 2.74 \\
3.23 \pm 2.43 \\
\end{array}$ & $\begin{array}{l}2.77 \pm 2.34 \\
0.97 \pm 1.33\end{array}$ & $\begin{array}{l}-9.25 \\
-53.00 \\
\end{array}$ & $\begin{array}{l}<0.01 * * * \\
<0.001 * * *\end{array}$ \\
\hline $\begin{array}{l}\text { Left } \\
\text { Control } \\
\text { Case }\end{array}$ & $\begin{array}{l}2.70 \pm 2.63 \\
3.10 \pm 2.37\end{array}$ & $\begin{array}{l}2.50 \pm 2.27 \\
0.87 \pm 1.28\end{array}$ & $\begin{array}{l}-5.92 \\
-55.50\end{array}$ & $\begin{array}{c}>0.10^{\mathrm{ns}} \\
<0.001^{* * *}\end{array}$ \\
\hline
\end{tabular}

Paired Student's T test $\mathrm{ns}=$ not significant $* * / * * *=$ significant

In table-Ill, the pain score of both hands in control subjects and the cases showed comparison and significance differences. Analysis shows that there was significant difference of percent change from before to after treatment (right side: control 9.25\% and cases $53 \%$; left side: control $5.92 \%$ and case $55.5 \%$ ) with $\mathrm{P}$ value $<0.01$ and $<0.001$ in control and case groups, respectively.

Table-IV Measurement of treatment response on numbness score in control $(n=30)$ and case $(n=30)$ groups

\begin{tabular}{|c|c|c|c|c|}
\hline \multirow[b]{2}{*}{$\begin{array}{l}\text { Numbness } \\
\text { Score }\end{array}$} & \multicolumn{2}{|c|}{ Measurement of response } & \multirow{2}{*}{$\begin{array}{l}\text { Percent }(\%) \text { change } \\
\text { from before } \\
\text { treatment to after } \\
\text { treatment }\end{array}$} & \multirow[b]{2}{*}{$P$ value } \\
\hline & $\begin{array}{c}\text { Before } \\
\text { treatment }(\text { Mean } \pm \mathrm{SD})\end{array}$ & $\begin{array}{l}\text { After treatment } \\
(\text { Mean } \pm S D)\end{array}$ & & \\
\hline $\begin{array}{c}\text { Right } \\
\text { Control } \\
\text { Case } \\
\end{array}$ & $\begin{array}{c}6.90 \pm 0.40 \\
6.67 \pm 1.37\end{array}$ & $\begin{array}{l}4.30 \pm 0.92 \\
2.87+0.94\end{array}$ & $\begin{array}{l}-37.68 \\
-55.40\end{array}$ & $\begin{array}{l}<0.001 * * * \\
<0.001 * * *\end{array}$ \\
\hline $\begin{array}{l}\text { Left } \\
\text { Control } \\
\text { Case }\end{array}$ & $\begin{array}{l}5.90 \pm 2.38 \\
6.17 \pm 2.15\end{array}$ & $\begin{array}{l}3.63 \pm 1.56 \\
2.73 \pm 1.05\end{array}$ & $\begin{array}{l}-33.73 \\
-51.83\end{array}$ & $\begin{array}{l}<0.001 * * * \\
<0.001 * * *\end{array}$ \\
\hline
\end{tabular}

Paired Student's V test $* * *=$ significant

The table showed the numbness score of both hands in control subjects and the cases. Their comparison and significance of differences are also given. Analysis shows that there was significant difference of percent change from before to after treatment (right side: control $37.8 \%$ and case $55.4 \%$; left side: control $33.73 \%$ and case $51.83 \%$ ) with $\mathrm{P}$ value $<0.001$ and $<0.001$ in control and case subjects, respectively.

Table-V Measurement of treatment response on tingling score incontrol $(n=30)$ and case $(n=30)$ groups

\begin{tabular}{|c|c|c|c|c|}
\hline \multirow[b]{2}{*}{ Tingling Score } & \multicolumn{2}{|c|}{ Measurement of response } & \multirow{2}{*}{$\begin{array}{c}\text { Percent }(\%) \text { change from } \\
\text { before } \\
\text { treatment to after treatment }\end{array}$} & \multirow[b]{2}{*}{$P$ value } \\
\hline & $\begin{array}{l}\text { Before treatment } \\
(\text { Mean } \pm S D)\end{array}$ & $\begin{array}{l}\text { After treatment } \\
(\text { Mean } \pm S D)\end{array}$ & & \\
\hline $\begin{array}{l}\text { Right } \\
\text { Control } \\
\text { Case }\end{array}$ & $\begin{array}{l}6.47 \pm 0.68 \\
6.17 \pm 1.49\end{array}$ & $\begin{array}{l}4.00 \pm 0.87 \\
2.93 \pm 0.87\end{array}$ & $\begin{array}{l}-38.05 \\
-50.73\end{array}$ & $\begin{array}{l}<0.001 * * * \\
<0.001 * * *\end{array}$ \\
\hline $\begin{array}{l}\text { Left } \\
\text { Control } \\
\text { Case } \\
\end{array}$ & $\begin{array}{l}5.47 \pm 2.27 \\
5.57 \pm 2.06\end{array}$ & $\begin{array}{l}3.57 \pm 1.57 \\
2.63 \pm 1.16\end{array}$ & $\begin{array}{l}-30.68 \\
-47.74\end{array}$ & $\begin{array}{l}<0.001 * * * \\
<0.001 * * *\end{array}$ \\
\hline
\end{tabular}

Paired Student's 't' test $* * *=$ significant 
Above table showed the tingling score of both hands in control and the cases. Their comparison and significance of difference are also given. Analysis shows that there was significance difference of percent change from before to after treatment (right side: control $38.05 \%$ and case $50.73 \%$; left side: control $30.68 \%$ and cases $47.74 \%$ ) with $\mathrm{P}$ value $<0.001$ in both control and cases.

Table-V1 Measurement of treatment response on tingling score in control $(n=30)$ and case $(n=30)$ groups

\begin{tabular}{|l|c|c|c|c|}
\hline \multirow{2}{*}{$\begin{array}{l}\text { Nocturnal } \\
\text { awakening score }\end{array}$} & \multicolumn{2}{|c|}{ Measurement of response } & $\begin{array}{c}\text { Percent (\%) change } \\
\text { from before } \\
\text { treatment to after } \\
\text { treatment }\end{array}$ & P value \\
\cline { 2 - 4 } Right & $\begin{array}{c}\text { Before } \\
\text { treatment(Mean } \pm \text { SD) }\end{array}$ & $\begin{array}{c}\text { After treatment } \\
(\text { Mean } \pm \text { SD) }\end{array}$ & -10.00 & $>0.05^{\mathrm{ns}}$ \\
$\quad$ Control & $1.47 \pm 1.17$ & $1.27 \pm 1.23$ & -66.67 & $<0.001^{* * *}$ \\
$\quad$ Case & $1.67 \pm 1.18$ & $0.23 \pm 0.63$ & & $>0.05^{\mathrm{ns}}$ \\
\hline Left Control & $1.27 \pm 1.23$ & $1.07 \pm 1.26$ & -10.00 & $<0.01^{* * *}$ \\
$\quad$ Case & $1.73 \pm 1.14$ & $0.23 \pm 0.63$ & -70.00 & \\
\hline
\end{tabular}

Paired Student's V test ns $=$ not significant $* * *=$ significant In the table, the nocturnal awakening score of both (right side: control $10 \%$ and cases $66.67 \%$ ); left hands in control and cases with the comparison and significance of difference are given. Analysis shows that there was significant difference of side: control $0 \%$ and cases $70 \%$ ) with $\mathrm{P}$ value 70.50 and $<0.001$ in control and cases, respectively. percent change from before to after treatment

Table-VII Measurement of treatment response on weakness score in control $(n=30)$ and case $(n=30)$ groups

\begin{tabular}{|c|c|c|c|c|}
\hline \multirow{2}{*}{$\begin{array}{l}\text { Weakness } \\
\text { score }\end{array}$} & \multicolumn{2}{|c|}{ Measurement of response } & \multirow{2}{*}{$\begin{array}{c}\text { Percent }(\%) \\
\text { change from } \\
\text { before treatment } \\
\text { to after treatment }\end{array}$} & \multirow[b]{2}{*}{$P$ value } \\
\hline & $\begin{array}{c}\text { Before } \\
\text { treatment(Mean } \pm \text { SD) }\end{array}$ & $\begin{array}{l}\text { After treatment } \\
(\text { Mean } \pm \text { SD })\end{array}$ & & \\
\hline $\begin{array}{c}\text { Right } \\
\text { Control } \\
\text { Case } \\
\end{array}$ & $\begin{array}{c}0.13 \pm 0.51 \\
0.63 \pm 1.00\end{array}$ & $\begin{array}{c}0.13 \pm 0.51 \\
0.27+0.69\end{array}$ & $\begin{array}{c}0.00 \\
-17.78 \\
\end{array}$ & $<0.05 *$ \\
\hline $\begin{array}{l}\text { Left } \\
\text { Control } \\
\text { Case }\end{array}$ & $\begin{array}{l}0.13 \pm 0.51 \\
0.60 \pm 0.93\end{array}$ & $\begin{array}{l}0.13 \pm 0.51 \\
0.20+0.61\end{array}$ & $\begin{array}{c}0.00 \\
-20.00\end{array}$ & $<0.05^{*}$ \\
\hline
\end{tabular}

Above the table showed the weakness score of both hands in control and cases. Their comparison and significance of difference are also given. Analysis shows that there was significant percent change from before to after treatment (right side: control $0 \%$ and cases $17.78 \%$; left side: control $0 \%$ and cases $20 \%$ ) with $\mathrm{P}$ value in cases subject $<0.05$, which was significant.

Table- VIII Measurement of treatment response on clumsiness score in control $(n=30)$ and case $(n=30)$ groups

\begin{tabular}{|c|c|c|c|c|}
\hline \multirow[b]{2}{*}{ Clumsiness score } & \multicolumn{2}{|c|}{ Measurement of response } & \multirow{2}{*}{$\begin{array}{c}\text { Percent }(\%) \text { change from } \\
\text { before treatment to after } \\
\text { treatment }\end{array}$} & \multirow[b]{2}{*}{$P$ value } \\
\hline & $\begin{array}{c}\text { Before } \\
\text { treatment }(\text { Mean } \pm \mathrm{SD})\end{array}$ & $\begin{array}{l}\text { After treatment } \\
(\text { Mean } \pm \text { SD })\end{array}$ & & \\
\hline $\begin{array}{l}\text { Right } \\
\text { Control } \\
\text { Case }\end{array}$ & $\begin{array}{l}0.60 \pm 0.93 \\
0.97 \pm 1.07\end{array}$ & $\begin{array}{c}0.60 \pm 0.93 \\
0.27+ \pm 0.69\end{array}$ & $\begin{array}{c}0.00 \\
-34.44\end{array}$ & $<0.001 * * *$ \\
\hline $\begin{array}{l}\text { Left } \\
\text { Control } \\
\text { Case }\end{array}$ & $\begin{array}{l}0.60 \pm 0.93 \\
0.97 \pm 1.07\end{array}$ & $\begin{array}{c}0.60 \pm 0.93 \\
0.27 \pm 0.69\end{array}$ & $\begin{array}{c}0.00 \\
-34.44\end{array}$ & $<0.001 * * *$ \\
\hline
\end{tabular}

Paired Student's V test $* * *=$ significant 
Above table showed the clumsiness score of both hands in control and cases. Their comparison and significance of difference are also given. Analysis shows that there was significant percent change from before to after treatment (right side: control $0 \%$ and cases $34.44 \%$; left side: control $0 \%$ and cases $34.44 \%$ ) with $\mathrm{P}$ value of cases subjects < 0.001 , which is highly significant.

\section{Discussion}

The age of the patients were matched for both the groups (mean+SD: control $38.73+7.25$ and case $39.47+7.90$ years) with no statistically significant difference $(\mathrm{P}>0.50)$, which is similar to the study done by Pruitt and Swift (2000), who found most of their patients with CTS were in 4060 years of age. In other studies, the peak incidence of CTS was found between 50 and 59 years. ${ }^{[5]}$ So, the incidence in this study was found to be little earlier than the western European studies. However, in a Brazilian study, de Campos et al. (2004) studied 215 CTS cases and their age ranged from 20 to 83 years with mean 41.6 years. In the present study, the mean age of the cases was 39.47 years and consistent with the Brazilian study.

In this study, sex distribution for both the control and cases were well-matched as well with no significant statistically difference $(\mathrm{P}>0.50)$. For CTS cases, male and female were $26.7 \%$ and $73.3 \%$ affected respectively. So, this study with Bangladeshi patients demonstrates that CTS is more common in females than males and found similar with other studies (de Crom et al., 1992; Atroshiet al., 1999). Besides, Western European studies found it 3 to 4 times more common in women than in men (Pruitt and Swift, 2000; Burke et al., 2003), which is well-consistent with results of the present study. Furthermore, the weight distribution, both the control and cases were wellmatched as well with no significant statistical difference $(\mathrm{P}>0.10)$ with the mean $( \pm \mathrm{SD})$ weight of control group was $58.83+5.59 \mathrm{~kg}$ and case $56.83+6.97 \mathrm{~kg}$.
In the Table-II, hyperesthesia in the distribution of the digital branches of the median nerve was $86.7 \%$ in control group and $83.3 \%$ in case group. Tinel's sign was positive in $90 \%$ in control group and $76.7 \%$ in case group. Whereas, Phalen maneuver was positive in $56.7 \%$ control and $56.7 \%$ cases.

Table-Ill of this study showed that pain score was reduced right side by $9.26 \%$ in control group and $53 \%$ in case group. Moreover, the left side 5.92\% reduced in control group and $55.5 \%$ in case group. This observation suggests that low-dose steroid is effective in CTS treatment. This study is consistent with the other study (Chang et al., 2002) which has showed $66 \%$ reduction in symptoms.

Table-IV of this study shows that the numbness score was reduced right side $37.68 \%$ in control and $55.4 \%$ in case group, while left side control $33.73 \%$ and cases $51.83 \%$. This observation suggested that low-dose steroid is effective in mild and moderate CTS patients, similar studies showed significant improvement of numbness score after low dose steroid. ${ }^{[6]}$

Tingling and numbness are considered as major or primary symptoms, hence more specific of CTS (Nathan et al., 1988; Nathan and Keniston, 1993; Naidu, 1999) Table-V of this study shows that the tingling score was reduced right side $38.05 \%$ in control and $50.73 \%$ in cases, left side control $30.68 \%$ and cases $47.74 \%$. This observation suggests that low-dose steroid is effective in CTS patients. As similar studies also showed significant improvement of tingling sensation in prednisolone group (Herskovitzet al., 1995), this observation has suggested that low-dose steroid is effective in CTS patients.

Table-VI of this study shows that the nocturnal awakening score was reduced right side control $10 \%$ and cases $66.67 \%$, left control $10 \%$ and cases $70 \%$. This observation suggested that prednisolone is effective in CTS patients. Similar study showed significant improvement of nocturnal awakening score in prednisolone-treated group. $^{[6]}$ 
Table-VII and Table-VIII of this study show that the weakness score improved right control $0 \%$ and cases $17.78 \%$, left control $0 \%$ and cases $20 \%$, clumsiness score improved right control $0 \%$ and cases $34.44 \%$, left control $0 \%$ and cases $34.44 \%$. This observation suggested that prednisolone is effective in mild and moderate CTS patients. Similar studies showed improvement of weakness and clumsiness score in prednisolone-treated group. ${ }^{[7]}$

Steroids are effective at reducing swelling on account of their anti-inflammatory action. Considering all the above observations, it is established that this study showed that oral steroid (prednisolone) in the treatment of mild to moderate carpal tunnel syndrome is effective.

\section{Conclusion}

It may be concluded that low-dose short-term oral prednisolone is an effective treatment of idiopathic carpal tunnel syndrome. Furthermore, this study would stimulate the necessity of further study in a larger scale in the future, which may be helpful for clinicians, researchers as well as health planners to contribute in better management of CTS. However, this study has some limitations, i.e. regarding long-term efficacy of oral steroid treatment remains uncertain. A further long-term study with larger sample size may help do determine the role of long-term efficacy of oral steroid.

\section{References}

1. Kimura J. 1989. Electrodiagnosis in diseases of nerve and muscle: princples and practices. 2nd ed. Philadelphia: FA Davis Company, pp.15-16, 25-33, 501-2.

2. Atioshi I, Gummensson C, Johnsson R, Ornstein E, Ranstam J, Rosen I. 1999. Prevalence of carpal tunnel syndrome in a general population. JAMA, Vol. 282:1538.
3. https://www.medicinenet.com/carpal_tunn el_syndrome/article.htm\#carpal_tunnel_sy ndrome_facts

4. Victor M, Ropper AH. 2001. Diseases of the peripheral nerves. In: Adam's and Victor's principles of neurology. 7th ed. New York: McGraw-Hill Books, pp.45-46, 1354-5, 1433-4.

5. Mondelli M, Glannini F, Glacchi M. 2002. Carpal tunnel syndrome incidence in a general population. Neurology, Vol. 58:289-94.

6. Herskovitz S, Berger AR, Lipton RB. 1995. Low dose, short term oral prednison in the treatment of carpal tunnel syndrome. Neurology, Vol. 45:1923-5.

7. Chang MH, Ger LP, Hsieh PF, Huang SY. 2002. A randomised clinical trial of oral steroids in the treatment of carpal tunnel syndrome: a long-term follow-up. J Neurol Neurosurg Phychiatr, Vol. 73:710-4. 